\title{
An Exploratory Study of School Librarians' Emotional Response to Change in the Workplace
}

\author{
Cynthia Houston \\ Western Kentucky University \\ Cynthia.houston@wku.edu \\ Andrea Paganelli \\ Western Kentucky University \\ Andrea.pagenelli@wku.edu
}

\begin{abstract}
Background. The library field is changing constantly as a result of changes in information access and technology innovations. Librarians are part and parcel of the change process, either as the initiators or primary recipient of change. Objectives. The goals of this study were to understand librarians' emotional responses during the change process and the types of changes they were experiencing. School librarians in the United States were the subjects of this study.

Methods. The study used exploratory survey methodology to gain a preliminary understanding of the types of changes school librarians were experiencing and how they were responding to these changes.

Results. Overall, school librarians reported that they experienced negative emotions as a response to change, particularly discouragement. The results of this study indicated that school librarians responded negatively to change when it was imposed externally. School librarians were more positive about change when they had some level of influence over the changes being made. Novice librarians were most positive about change. In all cases, school librarians felt slightly more positive about change over time.

Contributions. The results of this study indicate that there are parallels between the emotional responses of school librarians and teachers during times of change, which has implications for research on librarians in schools across the globe. The study shows that librarians with some influence have more positive experiences with change, which the researchers believe has implications for professional practice.
\end{abstract}

\section{INTRODUCTION}

In the workplace, change is inevitable. There will be personnel changes, reorganisations and changes made in response to technological or societal changes. In essence, workplace change is part of life. As the saying goes, "change happens."

Libraries as physical and organisational institutions have undergone many changes as technology, society's needs, and the format of library materials have changed. New libraries are built with more programming space and less space for print materials; technology staffing 
is increased, while subject librarian staffing decreases. According to Scott, Griffith, Wickett, Hine and Hopman (2011) "libraries are fundamentally reinventing themselves in order to remain a valued partner in achieving the missions of their institutions" (p. 396).

School libraries have also experienced dramatic changes over the past two decades, as the card catalog has given way to integrated library systems, and the learning commons concept has changed the concept of school libraries from warehouses to collaborative community spaces. According to Killeen (2010) school librarians are leaders of change in technology and teaching, but sometimes they are handed change that cause them stress and anxiety.

While all of us know that changes in our physical and organisational work life are part of being a member of a changing and growing institution, it doesn't make the actual process of changing easier. This is true significantly in the education profession, of which school librarians are members. Schools are constantly undergoing changes mandated by national, federal, state or district regulations, budgetary constraints, changes in technology, curriculum standards and teaching methods. According to Abrahamson (2004), the constant changes educational professionals experience year after year leads to what is referred to as "repetitive change syndrome" that often causes teacher burnout and disengagement in reform efforts. According to Hargreaves $(2004,2005)$, change is always accompanied by emotion-whether it is a negative or positive one. Because most educators are passionate about their profession and have personal investment in the way they work with students, it is very rare that teachers are apathetic about changes taking place around them (Nias, 1996). This is also true for library professionals, who according to Scott et al. (2011) rarely register no emotional response to change.

There is a prevalent concern among school librarians regarding changes in the library, as loss of space, staff and budget reductions are reported on international, national and state electronic discussion lists. National reports of the diminishing status of school libraries in the United States and in other countries also cause concern among school librarians (O'Connell, 2014). In a climate of change and reform, understanding how educators respond to change is essential for changes to be successful (Hargreaves, 2005). In order to help school librarians be the change agents they are expected to be, it is important to know the types of changes they are experiencing and what emotional responses accompany these change events.

In studies of change in education, emotional responses have often been considered to be a by-product of change and not a focus of study. However, attitudes toward change have been found to be strong predictors in the success of the change effort (Hargreaves, 2005). In recent years, researchers have begun to study the emotional response to change in the context of the types of changes that are occurring and the manner in which the changes are being made. Although there is a body of research on how teachers respond to change related to educational reform (Kelchtermans, 2005), there are currently no studies on school librarians' emotional responses to change. This disparity in research - coupled with the pace of changes occurring in schools and school libraries today-prompted these two researchers to begin to examine this area of study more closely. Of particular interest to us is exploring what changes are taking place in school libraries across the United States, developing a better understanding of how school librarians are responding to particular changes in schools, and determining the possible types of emotional responses school librarians are experiencing as a result of these changes. 


\section{RESEARCH QUESTIONS AND LITERATURE REVIEW}

To begin to explore this area of study, the researchers formulated the following questions for guidance:

What is the nature of librarians' emotional responses to internal and external changes?

What are the types of changes to which librarians are responding in their work environment?

Is there a relationship between librarian's response to change and the source of change, level influence, and impact of the change on the library before, during, and after the change?

Because change in the workplace affects employee morale and productivity, there is a great deal of research on this subject in the human resource management field. A well-known model of emotional stages in the organisational change process was adapted from the bereavement model proposed in 1969 by Kubler-Ross, which includes stages of denial, anger, bargaining, depression and acceptance (Freeman, 1999). According to Myers, Hulks and Wiggins (2012), these types of emotions associated with changes in the workplace play an important role in how successfully the change process is managed, regardless of whether it is a planned or emergent event.

There is also a substantial amount of research on educational change and its emotional impact on teachers, specifically related to educational reform (Kelchtermans, 2005). However, even though school libraries are often affected by change initiatives in schools, no studies have investigated the emotional impact of changes in school libraries on school librarians.

Jansen (2009) stated that emotion was once "the missing dimension in research on educational change" (p. 185). According to Hargreaves (2004), change and emotion are inseparable and "few teachers find that a change of principal, building, job, role or class does not impact their feelings in some fundamental way" (p. 288). In his research on teachers' emotional response to change, Hargreaves $(2004,2005)$ found that most teachers associated change with external or imposed change. Some teachers compared and contrasted external change with something that is unwanted, and internal change with self-initiated change that is desired. In these studies, mandated change was seen negatively, while self-initiated change was seen positively. Teachers' criticism of mandated change experiences included: not being consulted when changes were made; poor implementation of the change; and insufficient support during the change process. Emotions associated with mandated change included frustration, anger, annoyance, fear and hate. On the other hand, self-initiated change was seen positively and was associated with pride, satisfaction and feelings of accomplishment and excitement.

While there is little research on how school librarians respond to change, many professionals in the field write about school libraries and change, with a focus on providing strategies to help school librarians cope with the changes they experience (Killeen, 2010; Oberg, 2009). In these articles, school librarians were often referred to as change agents because at one time school libraries were considered educational innovations in themselves. School librarians were brought into schools to manage innovation and facilitate media utilisation and learning. According to Killeen (2010), "teacher-librarians are in the field of learning, change and growth. T-Ls are role models for students and staff in many areas and dealing with change provides another example of leadership in schools" (p. 61). Oberg 
suggests that school librarians should respond to change in an effective manner: "The challenge for the school library professional is to be an agent and catalyst for change within the whole school as well as within the school library" (p.22).

At an international level, research indicates school libraries in a number of different countries are experiencing changes resulting from technological change and budgetary challenges. O'Connell (2014) asserted that Australian school libraries had experienced declining resources and staffing due to competing priorities in the school and budgetary constraints, while in Britain, Shenton and Marshman (2012) reported that traditional school libraries were being replaced with resource centers with materials in electronic format. Although much has been written about school libraries and change, it is surprising that there is no research on the types of changes that are taking place in the library, or on how librarians are responding to change.

\section{METHODOLOGY}

According to Powell and Connaway (2004), a formative or exploratory methodology is used to help researchers become familiar with the situation of interest, clarify concepts, and develop research strategies. The researchers chose an exploratory survey methodology to begin our study of school librarians and change because we believed it would help us to better understand the nature of their experiences and provide insights for future research.

The researchers developed and administered an online survey instrument to garner descriptive cross-sectional information from K-12 librarians across the United States. Questions were developed to capture the current state of change in school libraries and the emotional responses of participating K-12 librarians across the country. The survey was distributed to a national population because we wanted to be assured that the responses provided as much variation in population demographics and geographical regions as possible. To achieve maximum geographic variation, the population chosen for the study were all members of the national school library professional listserv, LM_NET (http://lmnet.wordpress.com/). LM_NET is an electronic discussion listserv available nationally, with a membership of around 16,000.

The development of the survey instrument began with a review of discussions related to libraries and change on professional listservs, exploring scholarly literature on libraries, change, and education, developing a pilot survey instrument, and conducting a pilot study. These three stages culminated in the development of a final survey instrument designed to explore the guiding questions. The survey instrument is included in Appendix A.

As part of the instrument development process, the researchers evaluated responses from open professional school librarian listerservs. As part of this task, listserv postings related to librarians' emotional response to change were reviewed and coded thematically. This method allowed the researchers to identify emotional responses librarians expressed during the change process, which ranged from anger, sadness, frustration, and disappointment, to a few positive responses.

The organisation and structure of the survey instrument was adapted from one used in a study of academic librarians' emotional responses to change (Scott et al., 2011). In this study, the researchers analysed how "next generation" librarians perceived institutional change. Using questions from this instrument along with the list of emotional responses derived from our coding analysis, the researchers created a pilot survey instrument that best matched the change environment and emotional responses of our population. 
The researchers administered the pilot survey instrument to members of a professional conference for school librarians and university professors using the Qualtrics (qualtrics.com) online survey program. A QR code with a link corresponding to the survey was distributed to interested conference participants so they could easily take the survey on their mobile devices. The researchers found that although the pilot survey was accessed frequently it was completed at a reduced rate, indicating that the survey was too long or asked too many openended responses. As a result of the pilot study, the researchers concluded that usability needed to be addressed in the process of developing the final survey instrument.

The final version of the survey instrument used in the study contained 16 items that ranged from multiple choice, to multiple answer and open-ended questions. The survey items were organised into the following three sections: librarian demographics, the types of changes in the library, and emotional responses to change at different periods of time.

The demographic questions explored the respondents' geographic area, school population, and years of professional experience; questions pertaining to the library environment included types of scheduling and programing offered by the school library, and other assigned duties.

Questions related to changes in the library included those about the source of the change, the type of change, the impact of the change on patrons, and the respondents' influence over the change before, during and after the changes were made. Final questions on the survey asked respondents to select their emotional responses to change from a list of positive and negative emotions derived from our coding analysis. In addition to the list of emotional responses, we allowed respondents to enter open-ended responses in order to capture the widest amount of information related to the types of changes taking place in the library, the source of the changes, and degree of influence during the change process.

To recruit participants for this study, the researchers sent a link to the online survey instrument via an email posted to a national school library professional listserv LM_NET (http://lmnet.wordpress.com/) with an invitation to participate in the survey. We indicated that we were seeking school librarians to participate in a survey about their experience with change and associated emotional responses. All participants were informed their responses were anonymous. The initial page of the survey was the informed consent document. We did not make offers of reward for participation. The survey was posted to the listserv in the spring of 2014. Two weeks later, we posted another message to the listserv with a reminder to complete the survey. The survey was closed one week later.

\section{RESULTS}

Responses to the survey were downloaded for analysis three weeks after the administration of the survey instrument. A total of 111 responses were recorded in the Qualtrics survey software. Out of these responses, there were 64 completed surveys, indicating that many members of the listserv accessed but did not complete the survey. The number of completed surveys resulting from our query is not representative of the listserv population or the population of school librarians. However, the results do provide sufficient data to explore the emotional responses of school librarians as they experience change and suggest avenues for further research. 


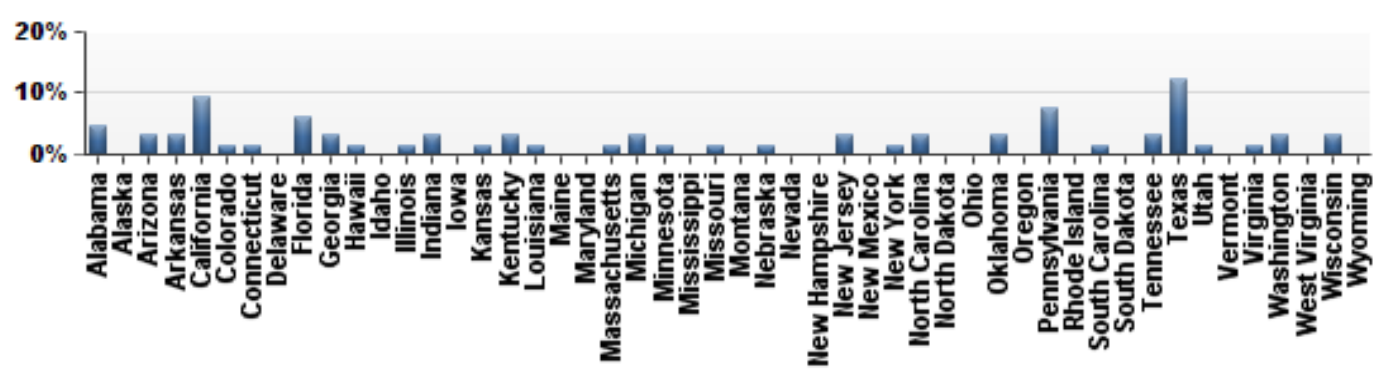

Figure 1. Geographic distribution of respondents by state

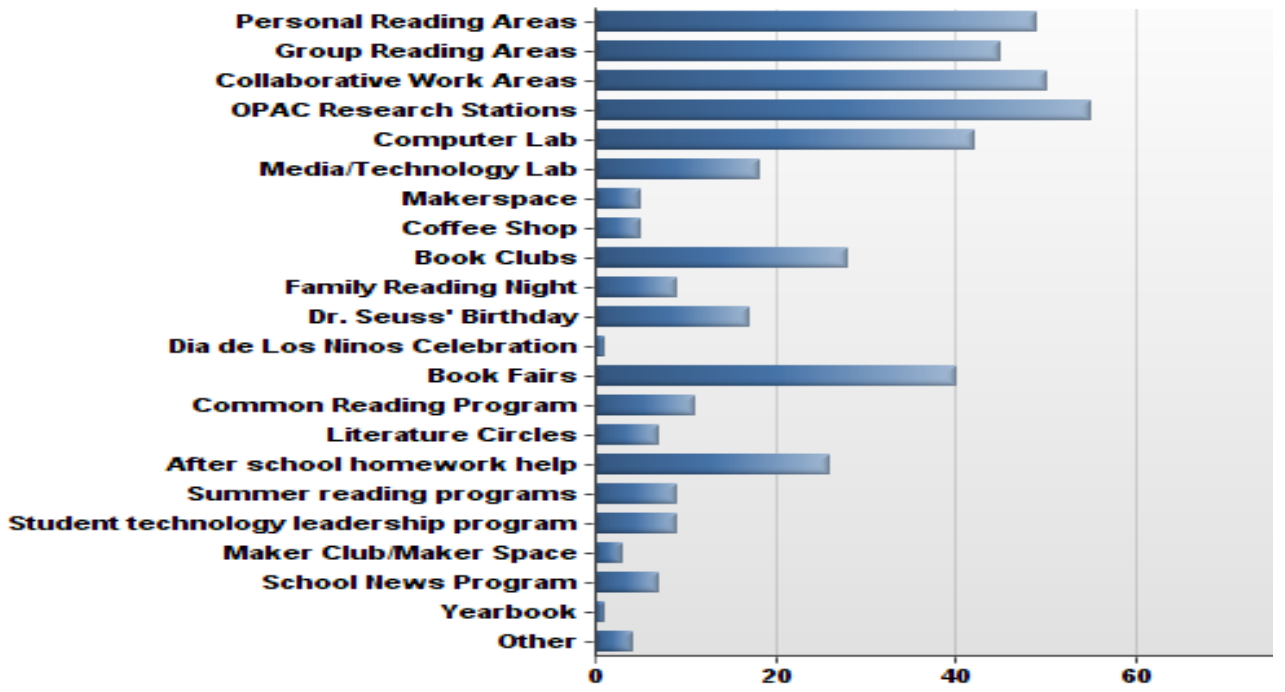

Figure 2. Library areas and services provided

\section{Demographics of the Respondents}

The respondents represented 31 out of 50 states in a wide geographic area, evenly distributed across the United States. These results are represented visually in the Figure 1.

An analysis of the demographics of our survey respondents indicates that they were primarily high school librarians, with some respondents from elementary schools, middle schools and libraries serving a mixed school population such as K-12. The respondents' levels of experience was weighted heavily toward veteran librarians, with 62 percent of librarians having more than ten years of experience, and 20 percent with five to ten years of experience. A majority of the school librarians responding to the survey reported they were on a flexible schedule (58 percent), with 22 percent reporting they were on a mixed fixed/flexible schedule, 19 percent reporting they were on a fixed schedule, and one percent identified as "other." The respondents reported they offered a variety of different programming spaces at their library. The graph in Figure 2 reflects the percentages of services provided.

\section{Changes in the Library}

Respondents were asked about the source of changes in their libraries. Most respondents replied that the changes were due to budget cuts (56 percent), while others reported changes 
due to a loss of staff ( 29 percent). When asked about those initiating the change, almost a third of the respondents indicated that changes were imposed by the Board of Education (30 percent). An additional 30 percent of librarians listed a number of other changes not listed in the survey, most of which indicated that a mix of forces such as the Superintendent and the Principal were initiating the changes. In 23 percent of the cases, the librarian was initiating the change.

When responding to questions about the level of influence they had over the changes, librarians indicated they had varied levels of influence. Many of the librarians indicated they had no influence over the changes, while others indicated they were influential. When asked about the impact of change on library patrons, a majority of librarians believed these changes had a high impact on patrons (61 percent), with 23 percent indicating the change had a medium impact, and 16 percent indicating the change had a low impact on patrons.

When asked about the impact of the change on library operations, 29 percent of the respondents indicated that the impact was very negative and 29 percent indicated that the impact was negative. On the other hand, 19 percent of the librarians indicated that the impact was positive and 24 percent indicated that the impact was very positive. Over all, the impact of changes in the library was somewhat negative, with 58 percent negative and 43 percent positive responses. Table 1 lists the type of changes respondents indicated were taking place in their school libraries.

\section{Librarians' Emotional Response to Change}

The survey results indicate that respondents experienced largely negative emotional responses to change before, during and after the change process. A majority of respondents reported they were discouraged before, during and after the changes. Conversely, approximately a third of the librarians reported they were excited about the changes in similar percentages before, during and after the changes. Over time, librarians became less discouraged and more confident about the changes as they went through the change process. It is interesting to note that throughout the change process, very few reported they were apathetic about the changes being made.

The survey results also indicate that school librarians had negative emotional responses from the types of changes they reported most often, such as budget cuts, loss of staff and changes in leadership. A majority of librarians reported they were discouraged about these changes, and many reported that they were also anxious and worried. Table 2 summarises librarians' emotional responses to the three most commonly reported changes before, during and after the changes.

Those school librarians who reported they had no influence over the change reported in the majority that they were discouraged, worried and angry. On the other hand, a majority of librarians who reported a high level of influence over the change reported they were excited, confident, and optimistic. Table 3 shows that as librarians reported they had increasing levels of influence in the change, they were increasingly more positive about the changes that were made.

School librarians were most negative about the changes that were made when the Principal or Board of Education initiated them. On the other hand, librarians were mostly positive when they were initiating the change. Table 4 shows that librarians were excited, optimistic and confident when they initiated the change. 
Table 1. Changes in the library

\begin{tabular}{|c|c|c|}
\hline $\begin{array}{l}\text { Changes in } \\
\text { the Library }\end{array}$ & Positive & Negative \\
\hline \multirow[t]{2}{*}{ Budget } & $\begin{array}{l}\text { Completed renovations } 3 \text { years ago. } \\
\text { Survived district's reduction in force } 2 \\
\text { years ago. When campus principal was } \\
\text { given charge of my budget for this year, } \\
\text { he reinstated my entire budget as } \\
\text { compared to some principal's who did not } \\
\text { give their librarian's any funds. }\end{array}$ & $\begin{array}{l}\text { As of this year, the entire library program } \\
\text { was cut to balance the budget. In } \\
\text { November, one of us was brought back to } \\
\text { service } 10 \text { buildings. }\end{array}$ \\
\hline & $\begin{array}{l}\text { Purchase of more online reference } \\
\text { materials and eBooks. }\end{array}$ & $\begin{array}{l}\text { In the past } 3 \text { years, we have changed from } \\
\text { a district with } 7 \text { school libraries and } 7 \\
\text { librarians to a campus with two librarians } \\
\text { serving } 7 \text { schools. There is a } \\
\text { paraprofessional at each campus and one } \\
\text { librarian for } 4 \text { elementary campuses and } \\
\text { one librarian for } 3 \text { secondary campuses. }\end{array}$ \\
\hline \multirow[t]{2}{*}{$\begin{array}{l}\text { Level of } \\
\text { Influence }\end{array}$} & $\begin{array}{l}\text { STAFFING: Went from two certified } \\
\text { library media specialists and one full- } \\
\text { time aide who were all on a 10-month } \\
\text { 20-day contract to one full-time certified } \\
\text { library media specialist on a 10-month } \\
\text { contract. They did not take away any of } \\
\text { my responsibilites nor any of my duties. } \\
\text { RE-ORGANISATION: Removed most } \\
\text { of my REF books and changed them to } \\
\text { nonfiction; changed my biographies and } \\
\text { integrated them within my nonfiction } \\
\text { collection. RENOVATION: Moved out } \\
\text { of a dilapidated building (leaks, mold, } \\
\text { mildew) into triple wide portable (leaks) } \\
\text { and then into a brand new space partially } \\
\text { designed by me...HEAVEN! }\end{array}$ & $\begin{array}{l}\text { I had no impact on some things that went } \\
\text { on ... staffing and working days, but the } \\
\text { other changes I have had a lot of impact } \\
\text { and am happy with the way that is going. } \\
\text { I had to "fight" to get a planning and duty } \\
\text { free lunch ... both are in my contract, but } \\
\text { neither were happening. Seems they } \\
\text { "forgot" I no longer had coworkers to } \\
\text { cover for each other as we take lunch or } \\
\text { need to go out of the LMC for planning or } \\
\text { booktalks etc. I am a union member and } \\
\text { had to get the union involved to get a 30- } \\
\text { minute duty free lunch and a } 30 \text { minute } \\
\text { planning period daily. }\end{array}$ \\
\hline & $\begin{array}{l}\text { We are currently renovating. We have } \\
\text { taken out five closets that used to have } \\
\text { the signs computer and typewriter over } \\
\text { them. Very old. We are putting in a } \\
\text { charging bar, stools and } 14 \text { chrome } \\
\text { books. We are repainting the entire } \\
\text { library. My office has been moved to a } \\
\text { closet that used to house overheads and } \\
\text { tvs. It is bigger and will have a new } \\
\text { window. My old small office will be } \\
\text { made in to a tech office. We are ordering } \\
\text { a } 60 \text { inch touch screen TV to mount on } \\
\text { the wall. And we still have lots of books } \\
\text { and kids are reading! }\end{array}$ & $\begin{array}{l}\text { The principal decided to close the library. } \\
\text { My position was cut. The books were } \\
\text { boxed up and move to another room. The } \\
\text { new room still does not have shelves for } \\
\text { the books and they are still in boxes. The } \\
\text { clerk that was hired to replace me does } \\
\text { not have any library duties since the } \\
\text { books are still boxed up. }\end{array}$ \\
\hline $\begin{array}{l}\text { Impact on } \\
\text { Patrons }\end{array}$ & $\begin{array}{l}\text { Re-organising by genre Serving teachers } \\
\text { more as they are busy and need resources }\end{array}$ & $\begin{array}{l}\text { The loss of our aid meant that our patrons } \\
\text { would no longer be able to have } \\
\text { classroom visits and instruction. It cut } \\
\text { down drastically on our library's } \\
\text { outreach. }\end{array}$ \\
\hline $\begin{array}{l}\text { Impact on } \\
\text { Operations }\end{array}$ & $\begin{array}{l}\text { We have adapted very well and are no } \\
\text { longer required to hire certified teachers. } \\
\text { The new assistants are highly vested in } \\
\text { our school since their children attend } \\
\text { here. We have made a challenging } \\
\text { transition into a productive new vitality } \\
\text { within our facility. }\end{array}$ & $\begin{array}{l}\text { There is very little library programming } \\
\text { and only students in grades } 3-5 \text { receive } \\
\text { instruction from a certified teacher } \\
\text { librarian. Our once award winning, robust } \\
\text { program has been destroyed. }\end{array}$ \\
\hline
\end{tabular}


Table 2. Emotional response to change by types of changes

\begin{tabular}{llllllllll}
\hline $\begin{array}{l}\text { Types of } \\
\text { Change }\end{array}$ & \multicolumn{3}{l}{ Budget Cuts } & \multicolumn{3}{c}{ Loss of Staff } & \multicolumn{3}{c}{$\begin{array}{c}\text { Changes in School } \\
\text { Leadership }\end{array}$} \\
\hline Emotion & Before & During & After & Before & During & After & Before & During & After \\
\hline Angry & 17 & 15 & 12 & 9 & 7 & 5 & 9 & 9 & 6 \\
& $44 \%$ & $41 \%$ & $35 \%$ & $47 \%$ & $37 \%$ & $29 \%$ & $53 \%$ & $56 \%$ & $40 \%$ \\
\hline Cynical & 11 & 9 & 11 & 6 & 5 & 5 & 6 & 5 & 6 \\
& $28 \%$ & $24 \%$ & $32 \%$ & $32 \%$ & $26 \%$ & $29 \%$ & $35 \%$ & $31 \%$ & $40 \%$ \\
\hline Anxious & 17 & 18 & 6 & 9 & 9 & 5 & 11 & 9 & 5 \\
& $44 \%$ & $49 \%$ & $18 \%$ & $47 \%$ & $47 \%$ & $29 \%$ & $65 \%$ & $56 \%$ & $33 \%$ \\
\hline Worried & 21 & 18 & 11 & 12 & 12 & 6 & 9 & 7 & 5 \\
& $54 \%$ & $49 \%$ & $32 \%$ & $63 \%$ & $63 \%$ & $35 \%$ & $53 \%$ & $44 \%$ & $33 \%$ \\
\hline Discouraged & 27 & 23 & 18 & 13 & 12 & 7 & 13 & 10 & 9 \\
& $69 \%$ & $62 \%$ & $53 \%$ & $68 \%$ & $63 \%$ & $41 \%$ & $76 \%$ & $63 \%$ & $60 \%$ \\
\hline Apathetic & 3 & 1 & 5 & 1 & 1 & 2 & 1 & 0 & 2 \\
& $8 \%$ & $3 \%$ & $15 \%$ & $5 \%$ & $5 \%$ & $12 \%$ & $6 \%$ & & $13 \%$ \\
\hline Optimistic & 8 & 9 & 8 & 5 & 5 & 4 & 4 & 3 & 5 \\
& $21 \%$ & $24 \%$ & $24 \%$ & $26 \%$ & $26 \%$ & $24 \%$ & $24 \%$ & $19 \%$ & $33 \%$ \\
\hline Excited & 8 & 6 & 10 & 3 & 4 & 6 & 4 & 2 & 4 \\
& $21 \%$ & $16 \%$ & $29 \%$ & $16 \%$ & $21 \%$ & $35 \%$ & $24 \%$ & $13 \%$ & $27 \%$ \\
\hline Confident & 4 & 7 & 9 & 2 & 2 & 5 & 1 & 2 & 4 \\
& $13 \%$ & $19 \%$ & $26 \%$ & $11 \%$ & $11 \%$ & $29 \%$ & $6 \%$ & $13 \%$ & $27 \%$ \\
\hline
\end{tabular}

Table 3. Emotional response to change by level of influence

\begin{tabular}{lllllllllllll}
\hline $\begin{array}{l}\text { Level of } \\
\text { Influence }\end{array}$ & \multicolumn{3}{c}{ No Influence } & \multicolumn{3}{c}{$\begin{array}{c}\text { Somewhat } \\
\text { Influential }\end{array}$} & \multicolumn{3}{c}{ Influential } & \multicolumn{3}{c}{$\begin{array}{c}\text { Highly } \\
\text { Influential }\end{array}$} \\
\hline Emotion & B & D & A & B & D & A & B & D & A & B & D & A \\
\hline Angry & 16 & 13 & 12 & 5 & 4 & 2 & 1 & 1 & 1 & 0 & 1 & 0 \\
& $55 \%$ & $45 \%$ & $46 \%$ & $29 \%$ & $25 \%$ & $13 \%$ & $9 \%$ & $9 \%$ & $9 \%$ & & $10 \%$ & \\
\hline Cynical & 10 & 8 & 10 & 3 & 3 & 3 & 2 & 2 & 0 & 1 & 0 & 0 \\
& $34 \%$ & $28 \%$ & $38 \%$ & $18 \%$ & $19 \%$ & $19 \%$ & $18 \%$ & $18 \%$ & & $10 \%$ & \\
\hline Anxious & 14 & 10 & 7 & 5 & 8 & 2 & 6 & 3 & 0 & 2 & 1 & 0 \\
& $48 \%$ & $34 \%$ & $27 \%$ & $29 \%$ & $50 \%$ & $13 \%$ & $55 \%$ & $27 \%$ & & $20 \%$ & $10 \%$ & \\
\hline Worried & 18 & 15 & 13 & 6 & 6 & 1 & 4 & 5 & 1 & 1 & 0 & 0 \\
& $62 \%$ & $52 \%$ & $50 \%$ & $35 \%$ & $38 \%$ & $6 \%$ & $36 \%$ & $45 \%$ & $9 \%$ & $10 \%$ & & \\
\hline Discouraged & 26 & 24 & 20 & 7 & 6 & 4 & 2 & 1 & 1 & 0 & 0 & 0 \\
& $90 \%$ & $83 \%$ & $77 \%$ & $41 \%$ & $38 \%$ & $25 \%$ & $18 \%$ & $9 \%$ & $9 \%$ & & & \\
\hline Apathetic & 4 & 1 & 4 & 0 & 0 & 1 & 0 & 0 & 0 & 0 & 0 & 0 \\
& $14 \%$ & $3 \%$ & $15 \%$ & & & $6 \%$ & & & & & & \\
\hline Optimistic & 0 & 3 & 0 & 5 & 5 & 6 & 6 & 7 & 7 & 8 & 6 & 5 \\
& & $10 \%$ & & $29 \%$ & $31 \%$ & $38 \%$ & $55 \%$ & $64 \%$ & $54 \%$ & $80 \%$ & $60 \%$ & $50 \%$ \\
\hline Excited & 2 & 2 & 3 & 7 & 4 & 5 & 5 & 5 & 6 & 7 & 9 & 7 \\
& $7 \%$ & $7 \%$ & $12 \%$ & $41 \%$ & $25 \%$ & $31 \%$ & $45 \%$ & $45 \%$ & $55 \%$ & $70 \%$ & $90 \%$ & $70 \%$ \\
\hline Confident & 0 & 2 & 1 & 2 & 2 & 6 & 4 & 5 & 4 & 5 & 5 & 1 \\
& & $7 \%$ & $4 \%$ & $12 \%$ & $13 \%$ & $38 \%$ & $36 \%$ & $45 \%$ & $36 \%$ & $50 \%$ & $50 \%$ & $10 \%$ \\
\hline
\end{tabular}


Table 4. Emotional response to change by the source of change

\begin{tabular}{llllllllll}
\hline $\begin{array}{l}\text { Source of } \\
\text { Change }\end{array}$ & \multicolumn{3}{c}{ Librarian } & & & Principal & & \multicolumn{3}{c}{$\begin{array}{c}\text { Board of } \\
\text { Education }\end{array}$} \\
\hline Emotion & Before & During & After & Before & During & After & Before & During & After \\
\hline Angry & 1 & 2 & 1 & 4 & 3 & 2 & 10 & 8 & 6 \\
& $6 \%$ & $13 \%$ & $7 \%$ & $44 \%$ & $33 \%$ & $22 \%$ & $48 \%$ & $38 \%$ & $32 \%$ \\
\hline Cynical & 3 & 2 & 0 & 2 & 2 & 3 & 6 & 5 & 4 \\
& $19 \%$ & $13 \%$ & & $22 \%$ & $22 \%$ & $33 \%$ & $29 \%$ & $24 \%$ & $21 \%$ \\
\hline Anxious & 5 & 2 & 1 & 3 & 2 & 2 & 9 & 10 & 3 \\
& $31 \%$ & $13 \%$ & $7 \%$ & $33 \%$ & $22 \%$ & $22 \%$ & $43 \%$ & $48 \%$ & $16 \%$ \\
\hline Worried & 7 & 4 & 0 & 6 & 4 & 3 & 10 & 10 & 5 \\
& $44 \%$ & $27 \%$ & & $67 \%$ & $44 \%$ & $33 \%$ & $48 \%$ & $48 \%$ & $26 \%$ \\
\hline Discouraged & 1 & 1 & 1 & 6 & 6 & 5 & 16 & 13 & 9 \\
& $6 \%$ & $7 \%$ & $7 \%$ & $67 \%$ & $67 \%$ & $56 \%$ & $76 \%$ & $62 \%$ & $47 \%$ \\
\hline Apathetic & 0 & 0 & 0 & 0 & 0 & 3 & 3 & 1 & 1 \\
& & & & & & $33 \%$ & $14 \%$ & $5 \%$ & $5 \%$ \\
\hline Optimistic & 9 & 10 & 8 & 1 & 2 & 1 & 5 & 2 & 3 \\
& $56 \%$ & $67 \%$ & $53 \%$ & $11 \%$ & $22 \%$ & $11 \%$ & $24 \%$ & $10 \%$ & $16 \%$ \\
\hline Excited & 9 & 10 & 10 & 2 & 1 & 1 & 5 & 3 & 4 \\
& $56 \%$ & $67 \%$ & $67 \%$ & $22 \%$ & $11 \%$ & $11 \%$ & $24 \%$ & $14 \%$ & $21 \%$ \\
\hline Confident & 5 & 6 & 6 & 0 & 1 & 2 & 1 & 1 & 6 \\
& $31 \%$ & $40 \%$ & $40 \%$ & & $11 \%$ & $22 \%$ & $5 \%$ & $5 \%$ & $32 \%$ \\
\hline
\end{tabular}

\section{DISCUSSION}

The results of this exploratory survey of school librarians' response to change indicate that change is a negative experience for school librarians when it is imposed on them externally, and they have little or no influence over the changes being made. Overwhelmingly, school librarians listed discouragement as the most commonly experienced emotion, possibly due to the impact they believed these changes had on library patrons and the operation of the library. A majority of school librarians also listed anger, worry and anxiety as their responses to changes, which persisted before, during and after the change. For most of these librarians, the changes were the result of budget cuts.

Although the results of an exploratory study such as this cannot lead to generalisations, they do provide insights into the research questions posed by this study. The emotional responses to change by the school librarians responding to this survey were largely negative when the change was imposed externally, and largely positive when the change was selfinitiated. These findings concur with research conducted by Hargreaves $(2004,2005)$ on teachers' emotional responses in the context of educational reform. Their studies indicated that when teachers initiated change or had influence over the changes being made, their emotional responses to the experience were more positive. In contrast, when changes were externally imposed, teachers were more negative about the change. An additional finding from our exploratory study that should be investigated further is that regardless of the source of change, school librarians' emotional responses to change became slightly more positive over time.

In this study, school librarians were often responding to budgetary changes, such as budget cuts and loss of staff. Reports from the National Council for Educational Statistics indicate a downward trend in the number of school libraries in the United States and that 25 
states had budget cuts due to revenue shortfalls (Davis, 2009). Hargreaves' (2004) study found that teachers were responding to educational or curricular reform, which is in contrast to the results of this study. It may be that school librarians, although they too are affected by educational reform initiatives, also manage a separate institution existing within a school that is very vulnerable to exigencies of funding formulas and revenue allocations. This makes school librarians' experiences and responses to change somewhat unique.

The strongest finding in this study is that school librarians' level of influence plays an important role in how they respond to the changes being made. Librarians were more positive about change when they had influence over the changes being made. They were the most positive about the changes they initiated as opposed to changes imposed on them. Specifically, librarians were most negative about change when they were initiated by the Board of Education. Conversely, they were more positive about changes when they had even a small level of influence. These findings concur with other studies related to educational change and reinforce the fact that when professionals have some level of influence or control over the changes being made, they will report a more positive experience (Hargreaves, 2004, 2005; Scott et al. 2011).

\section{CONCLUSION}

The ideas and insights from this exploratory study of school librarians' experience with change are important to all school librarians who are facing changes in their professional lives, and are also relevant to administrators who are managers of the change process in their schools. The survey results indicate that the types of changes librarians experience have a lot to do with the financial health of the nation, state, school district and school libraries. Given this fact, library professionals and institutions must recognise their vulnerability.

From an international perspective, educational research in different countries indicates that change is difficult for teachers and the pace of change is often exhausting (Ibrahim, AlKaabi, \& El-Zaatari, 2013). Sikes' research (1992) found that imposed change in education is a reality in many countries and often pits official authorities against the professional experience, judgment and expertise of veteran teachers, resulting in a negative working environment. School librarians across the globe also face challenges of how others view their changing roles. For example in South Africa, research on the role of school librarians found that school librarians expressed frustration because their position in the school was not well understood. According to Paton-Ash and Wilmot (2015), "unless teachers see the library and the school librarian as part of the teaching and learning programme of the school and embedded in the curriculum, the role of the library will continue to be peripheral" (p. 7). Likewise, according to Marquardt \& Oberg (2011), school librarians in every country must prove over and over again "their worth, to show their active role in the school community, to position themselves to gain consideration, support and funds" (p.4).

The results of this exploratory research add to a body of research on organisational change and emotion in the teaching profession. Research indicates that repetitive change in schools resulting from educational reform initiatives may cause low morale and productivity in the educational workforce. While the results of this study indicate that financial issues are driving change in school libraries, the same kind of negative emotions among the school librarian workforce are present. Given this finding, the negative impact of external changes where teachers and librarians have no influence should be of great concern to school administrators at all levels. 
As mentioned previously, the results of this study are not generalisable and the respondents may not represent the national population of school librarians. For this reason, it is not known if the results are biased towards librarians in secondary schools with 5 or more years of experience who comprised the majority of our respondents, or if this is characteristic of the whole population of school librarians. Furthermore, as these school librarians perceive change to be a negative experience, they may under report positive changes that occur for which they do not register strong emotions.

It is our desire that the initial findings from this study will begin a conversation about change in the school library and how we as a profession perceive and respond to change. As this was a fairly small survey with a restricted number of respondents, future research should be done to confirm these findings and to explore themes that have emerged from this study. For example, if school librarians are more positive about changes they have influenced, how have these librarians been able to manage the change process so that they have influence? It would also be of interest to explore the area of librarians and change by using a more qualitative case study research method. Looking at school librarians who express positive feelings toward change can help to determine if there are specific personal traits or enabling and disabling factors that can be associated with positive emotional responses to change and effective professional advocacy. In 1963 John F. Kennedy said, "Change is the law of life. And those who look only to the past or present are certain to miss the future." Let us not miss the future.

\section{REFERENCES}

Abrahamson, E. (2004). Change without pain: How managers can overcome initiative overload, organizational chaos, and employee burnout. Boston: Harvard Business School.

Davis, D. (2009). The condition of U.S. libraries: School library trends 1999-2009. Chicago, IL: American Library Association Office of Research and Statistics. Retrieved from http://www.ala.org/research/sites/ala.org.research/files/content/librarystats/librarymedia center/Condition_of_Libraries_1999.20.pdf

Freeman, S. F. (1999). Identity maintenance and adaptation: A multilevel analysis of response to loss. In B. Staw \& M. Sutton (Eds.), Research in organizational behavior (21st ed.). Greenwich, CT: JAI Press.

Gavigan, K., Pribesh, S., Dickinson, G. (2010). Fixed or flexible schedule? Schedule impacts and school library circulation. Library \& Information Science Research, 32(2), 131137.

Hargreaves, A. (2004). Inclusive and exclusive educational change: Emotional responses of teachers and implications for leadership. School Leadership \& Management, 24(2), 287-309.

Hargreaves, A. (2005). Education change takes ages: Life, career and generational factors in teachers' emotional responses to educational change. Teaching and Teacher Education, 21, 967-983.

Ibrahim, A., Al-Kaabi, A., \& El-Zaatari, W. (2013). Teacher resistance to educational change in the United Arab Emirates. International Journal of Research Studies in Education, 2(3), 25-36.

Jansen, J. (2009). When politics and emotions meet: Educational change in racially divided communities. In A. Hargreaves \& M. Fullan (Eds.), Change Wars. Bloomington, IN: Solution Tree. 
Kelchtermans, G. (2005). Teachers' emotions in educational reforms: Self-understanding, vulnerable commitment, and micropolitical literacy. Teaching and Teaching Education, 21(8), 995-1006.

Kennedy, J. F. (1963). Address in the Assembly Hall at the Paulskirche in Frankfurt, June 25, 1963. Retrieved from http://www.presidency.ucsb.edu/ws/?pid=9303

Killeen, E. (2010). New beginnings or coping with change. Teacher Librarian, 38(1), 60-61.

Marquardt, L., \& Oberg, D. (Eds.). (2011). Global perspectives on school libraries: Projects and practices (IFLA publications 148). Berlin: De Gruyter Saur.

Myers, P., Hulks, S., \& Wiggins, L. (2012). Organizational change: Perspectives on theory and practice. London: Oxford University Press.

Nias, J. (1996). Thinking about feeling: The emotions in teaching. Cambridge Journal of Education, 26(3), 293-306.

Oberg, D. (2009). Libraries in school: Essential contexts for studying organizational change and culture. Library Trends, 58(1), 9-25.

O'Connell, J. (2014). Researcher's perspective: Is teacher librarianship in crisis in digital environments? An Australian perspective. School Libraries Worldwide, 20(1), 1-19.

Paton-Ash, M., \& Wilmot, D. (2015). Issues and challenges facing school libraries in selected primary schools in Gauteng Province, South Africa. South African Journal of Education, 35(1), 1-10.

Powell, R. R., \& Connaway, L. S. (2004). Basic research methods for librarians. Westport, Conn: Libraries Unlimited.

Scott, L., Griffith, G., Wickett, S., Hine, K., \& Hopman, W. (2011). Scary, exciting, or something in-between: How do next generation academic librarians perceive institutional change? In Proceedings of the ACRL Annual Conference, April 2011, Philadelphia, PA. Retrieved from http://www.ala.org/acrl/sites/ala.org.acrl/files/content/conferences/confsandpreconfs/na tional/2011/papers/scary_exciting.pdf

Shenton, A. K., \& Marshman, G. (2012). The school library of today: Guises and "universal" roles. School Libraries Worldwide, 18(2), 73-81.

Sikes, P. (1992). Imposed change and the experienced teacher. In M. Fullan \& A. Hargreaves (Eds.), Teacher development and educational change (pp. 36-55). London: Routledge. 


\section{APPENDIX A: LIBRARIAN RESPONSE TO CHANGE SURVEY}

Select the state where you work as a school librarian.

What school population does your library serve?

C Primary

C Elementary

C Middle grades

C Secondary

C Other

How many years of experience do you have as a school librarian?
Less than a year
1 to 5 years
6 to 10 years
more than 10 years

C

C

C

C

Select any duties required of you in addition to your library duties.

$\lceil$ School Technology Leader

ᄃ School Committees

$\ulcorner$ Before and After School Duties

$\ulcorner$ Other

Select the type of scheduling used in your library

$\mathbf{C}$ Fixed schedule

C Flexible schedule

C Mixed fixed/flexible schedule

C Other

Select any of the following offered by your library

$\ulcorner$ Personal Reading Areas

$\Gamma$ Book Fairs

$\ulcorner$ Group Reading Areas

$\Gamma$ Common Reading Program

$\Gamma$ Collaborative Work Areas

$\Gamma \quad$ Literature Circles

$\ulcorner$ OPAC Research Stations

$\Gamma$ Book Clubs

$\ulcorner$ Computer Lab

$\Gamma$ After school homework help

Г Media/Technology Lab

$\ulcorner$ Summer reading programs

$\Gamma$ Makerspace

$\Gamma$ Student technology leadership program

$\ulcorner$ Coffee Shop

$\ulcorner$ Maker Club/Maker Space

$\ulcorner$ Family Reading Night

$\Gamma$ School News Program

$\Gamma$ Dr. Seuss' Birthday

$\ulcorner$ Yearbook

$\ulcorner$ Dia de Los Ninos Celebration

$\ulcorner$ Other 
Please describe any significant changes in the past or currently taking place at your library (e.g. budget cut, renovation, re-organisation, staffing changes)

Select the source which best describes who is initiating the change in your library.

C I am initiating the change (librarian)

C The school principal is initiating the change

C The school council is initiating the change

C The Board of Education is initiating the change

C The change is initiated by external funding e.g. a grant

C Other

In your opinion, what are the reasons for the change? (check all that apply)

$\Gamma$ Budget cuts

$\Gamma$ New funding

Loss of staff

ए New hire

$\ulcorner$ Change in leadership at the school building level

$\ulcorner$ Change in leadership at the school district level

$\ulcorner$ Reports from consultants

Other

Select specific emotions to describe your initial feelings when you learned of the changes to be made. (select all that apply) Please provide additional details about this event in the text box.

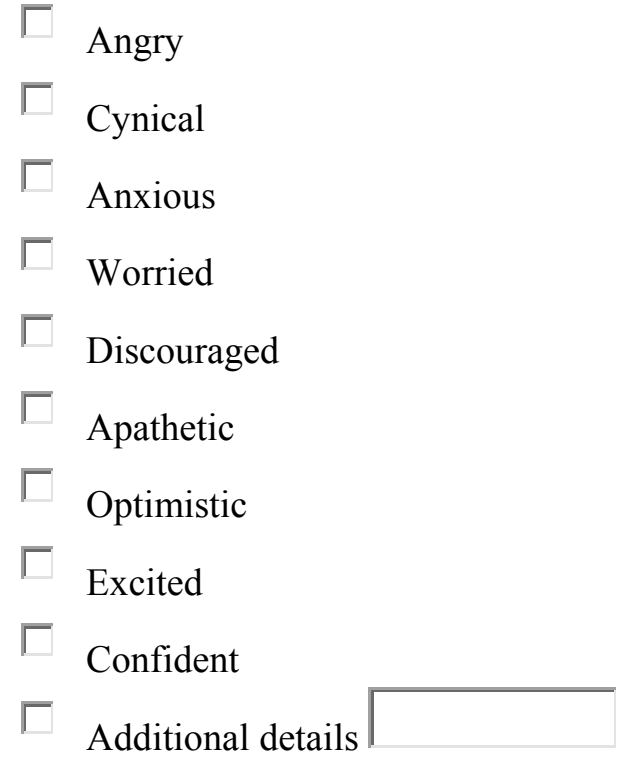


Select responses from "Angry" to "Confident" to describe your feelings while the changes were being made. (select all that apply) Please provide additional details about this event in the text box.

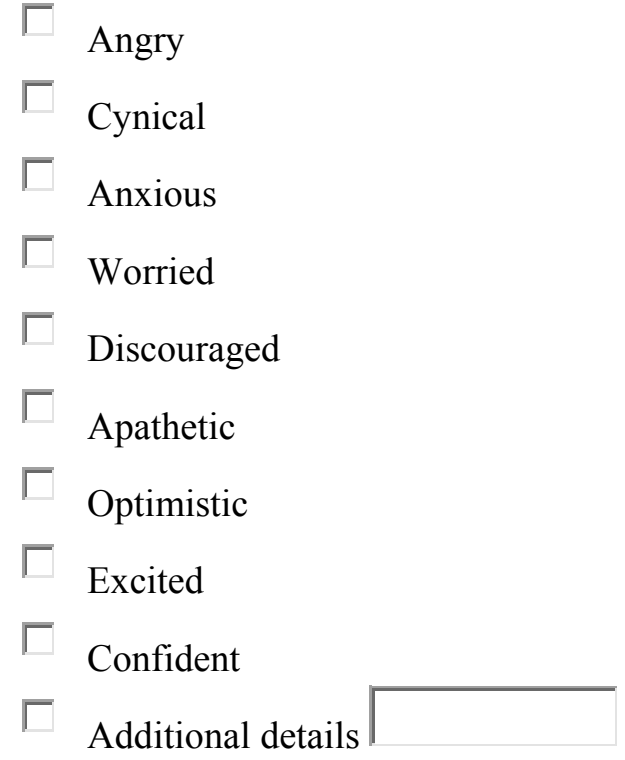

Choose responses from "Angry" to "Confident" to describe your feelings after the changes were made. (select all that apply) Please provide additional details about this event in the text box.

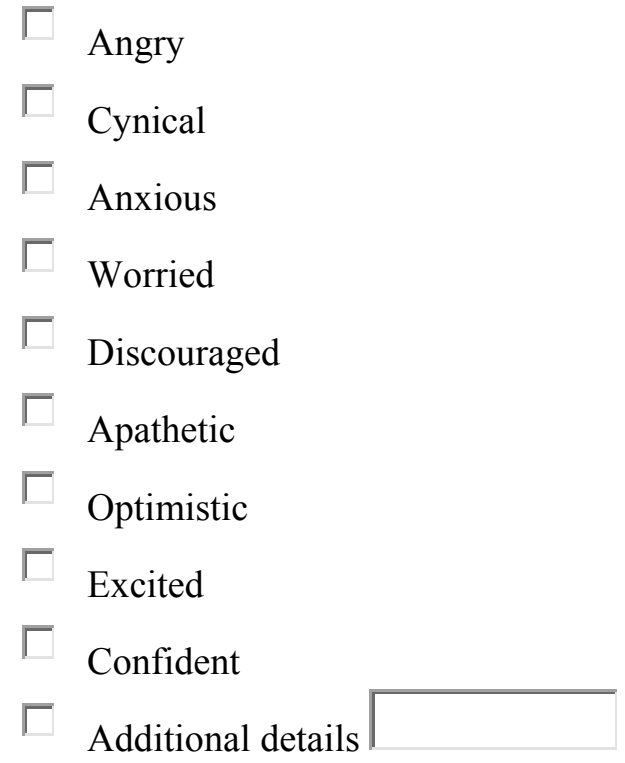

Rate from "No Influence" to "Highly Influential" your level of influence in how the changes were implemented?
C No Influence
C Somewhat Influential
C Influential
C Highly Influential 
Libres volume 25, issue 1, pages 16-32 (2015)

Rate from "Low impact" to "High impact" your your opinion on the overall impact of the change on the library's patrons.
C Low impact
C Medium impact
C High impact

Rate from "Very Negative" to "Very Positive" your opinion on the overall effect of the change on the operation of the library.
C Very Negative
C Negative
C Positive
C Very Positive

Please elaborate on the situations surrounding changes in the library, its effects on library staff and/or its patrons. 